\title{
Additional Texts that May Belong to the mašmaššu-phase
}

This chapter contains a discussion of tablets that based on text-internal criteria, may be assigned to the mašmaššu- or mašmaš bit Aššur-phases of Kiṣir-Aššur's career. ${ }^{1}$ At least 14 of Kișir-Aššur's tablets do not provide his professional title and as many as 16 texts contain breaks in the colophons where a potential title would have been. As such, these tablets cannot be distributed properly to Kișir-Aššur's various career phases at present. However, certain features in the colophons can be used to propose a tentative assignment of some of these texts to certain career phases proximal to the mašmaššu-phase. Furthermore, the only dated tablet by Kișir-Aššur, and the Bāba-šuma-ibni family in general, KAR 267, is found among the tablets without titles, and this text will be discussed in order to assign this text to a section of Kișir-Aššur's career.

Kișir-Aššur's mašmaššu-phase tablet $L K A 115$ is the first text from any career phase that employs what will be referred to here as a "purpose statement". I use this term to refer to statements, which designate that the tablet was produced "for undertaking a (ritual) procedure" (ana șabāt epēši). By extension, such phrases are indicative of the texts' pragmatic purpose (e.g., Maul 2010a: 212-13; Hunger 1968: 12, 19-20). Outside of career phases, such statements are also found in nine of Kișir-Aššur's tablets without titles and in seven tablets with broken colophons. The present chapter argues that such statements are useful as a distributive criterion. Several manuscripts, including Kișir-Aššur's only commentary-like text without a title, $B A M \quad 307$, also indicate they were copied at the request of Kișir-Aššur ([ú-š] aš-țir-ma). Therefore, this chapter also discusses Kișir-Ǎšsur's use of assistants to copy relevant material.

\section{1}

\section{Omission and Inclusion of Titles}

The written name serves the purpose of remembrance, claiming ownership over the text as an object, or providing authority (Maul 2010a: 215 and note 94; Radner 2005: 70, 169). Perhaps for this reason, several of Kișir-Aššur's colophons

1 The title mašmaš bit Aššur "Exorcist of the Aššur temple" designates the last traceable phase of Kișir-Aššur's career, which appears after his mašmaššu-phase. It is treated in Chapter 8. 
include the phrase: "Do not erase my written name". 2 Titles are additional elements that reference the level of competence within the professional group of which a copyist or writer was part. ${ }^{3}$ All this information was stored in the colophons. The purposes of colophons differ over time, place and within individual careers, as discussed in Section 1.1 (cf. Gesche 2001: 153-54; Hunger 1968: 1, 15ff.; Leichty 1964: 147). However, while a copy frequently presents itself as the transmission of an ideally static textual tradition, Stevens (2013: 212) stated that the colophons must have served as the textual area for individual scholarly touch wherein scribes could practice "free choice over form and content". Still, Stevens (2013: 220 note 54) argued that colophons from advanced levels of scholarship tend to be more elaborate than earlier colophons, but in general this is not true of Kișir-Aššur's colophons with titles.

Although the reasons for the addition or omission of titles in colophons is uncertain, a fair assumption may be that it depended on the audience, i.e., who was supposed to read the product in the present and future. Titles were included for both the scribe and his ancestors, although many works - some of which were integrated and preserved in tablet collections - were not supplied with a colophon at all (Hunger 1968: 9-11; Leichty 1964: 153). Comparative NB and LB material suggests that student or apprenticeship titles were not used during education before the professional specialization (Gesche 2001: 153ff., 213). ${ }^{5}$ The question is therefore whether or not Kiṣir-Aššur could or would omit his apprenticeship title during his earlier attested phases. During his later career stages the purposes of the text may be indicative of who was supposed

2 Šamallû șehru title: $B A M$ 9, RA 15 pl. 76, RA 40 pl. 116; mašmaš büt Aššur title: Beckman and Foster 1988 no. 21, LKA 77. For quotations, see Appendix 1. It is unclear if names could actually be removed from tablets by applying, e.g., water to the colophon (see Taylor 2011: 19, 22; van de Mieroop 2006: 274, concerning erasing names from inscriptions). Maul (1994: 221) discusses the possibility that adding a name and stating that the person with this name wrote the tablet could bestow a benign divine effect on the copyist.

3 By extension, a title communicates professional credentials and identity to the reader. However, the recipient of a text, i.e., its reader(s), may have changed from text to text.

4 See also Rochberg 2004: 211. Yet, Stevens (2013: 212 note 6) argues the LB Uruk colophons show order in variation of elements, wording and sign choices in the colophon (see Robson 2011a: 566-69; cf. Lenzi 2008a: 206).

5 Gesche (2001:153) seems to differentiate between school and library tablets' colophons in the sense that the former were often dedicatory and the latter contained "Bibliotheksvermerken". As such, especially the NB school texts donated to the Nab̂ै-ša-harê temple in Babylon were dedicated to this temple and by extension Nabû (Charpin 2010a: 47; Cavigneaux 1999a: $385^{-}$ 86; Cavigneaux 1981: 9-10, 37ff., 79-80, 101-2, 117-18, 125-26, 135ff.). Thus, such tablets with colophons likely functioned as votive objects in the temple (George 2003-04: 404; Gesche 20o1: 153, 155, 158-6o). Copying traditional texts may occasionally have been considered a service to the gods. 
to read it, and consequently, whether or not a title was necessary. Perhaps certain "quickly extracted" tablets with purpose statements were produced rapidly (Maul 2010a: 213-14, 216). One possible result of the time constraints and the pragmatic purpose of such texts may have been that the copyist wrote minimalistic colophons.

Generally, texts copied during various training phases probably served the dual purpose of posing as an exercise in copying as well as providing a basis for practical training. ${ }^{6}$ Nonetheless, the standard of šamallû șehru manuscripts must occasionally have been high, since there are several examples of such manuscripts being integrated into contemporary text collections (see Robson 2014: 152-53). ${ }^{7}$ This is one possible reason why several of Kișir-Aššur's elaborate colophons appear during his šamallû șehrru-phase. If so, the colophon likely served the purpose of creating an image of Kișir-Ǎšsur as a skilled apprentice. Still, Kiṣir-Aššur may also have produced manuscripts without colophons, and the purpose of the colophon is therefore not always clear.

The recipient(s) of many of Kișir-Aššur's texts with colophons is uncertain. Nevertheless, even tablets with purpose statements were likely integrated into the tablet collection (Maul 1994:169), although it is unknown if they were used after the specific ritual for which they were copied. Maul (2010a: 215) suggests the accumulation of tablets into a collection could be regarded as a means of identification of personal qualifications for individuals such as Kișir-Aššur. It may be that tablets without titles stem from later career phases in which the tablets would only be used by Kișir-Aššur, e.g., with purpose statements in relation to a ritual, or that Kișir-Aššur did not need a title to boost his image in particular texts. However, this remains speculative. The fact remains that Kișir-Aššur included a title in the majority of his colophons for reasons that are often unclear. I therefore find it unlikely that Kișir-Aššur would have copied, e.g., šamallû șehru tablets with colophons that omit both his title and the $\check{s} a$ Nabû tuklassu-phrase (Section 5.4).

6 Robson 2013: 40; Schwemer 2011: 422; Maul 2010: 216-17; Geller 2010: 130-31; Beaulieu 2007a: 475-76; cf. Gesche 2001: 197, 212-13.

7 Whether these new copies were dedicated to the library as part of the training, they replaced older manuscripts, or were dedicated to, e.g., Nabû in connection with being placed in the library typically cannot be determined (cf. Clancier 2014: 46; Robson 2014: 150, 152-53; Cavigneaux 1981: 5). Although the NB school tablets from Babylon were often schoolwork, they were still kept in the temple as part of the floor filling, likely because they were dedicated to Nabû on behalf of the future scribe (Cavigneaux 1999a: 388). Maul (2010: 217), however, stressed that some $\mathrm{N}_{4}$ tablets without colophons contain poor spellings and a bad script (see Robson 2014: 154). 
There are in total 15 tablets without titles that may have belonged to KișirAššur's mašmaššu-phase or later. It is unclear why these colophons do not mention his title explicitly, especially because some of the colophons do mention the titles of his forefathers. In addition to an overview of Kișir-Aššur's tablets without titles, this section includes a summary of textual features that are useful for suggesting possible phases wherein these tablets were copied. Table 12 contains an overview of the texts, divided into three groups according to the content of the texts, namely: medical texts, ritual texts, and texts relating to other areas of technical literature.

The diagnosis and prescription texts were directed against head maladies $(B A M 9)$, a specific eye illness $(B A M 351),{ }^{8}$ internal problems connected to the spleen(?) (BAM 78), ${ }^{9}$ the lower body illness ša ššațu and associated stiffness (BAM 131), and finally feet maladies $(B A M 121) .{ }^{10}$ Several tablets only contain incantations or prayers, ${ }^{11}$ whereas others contain both incantations and rituals to combat ghosts (KAR 21, KAR 267), a diagnosis and an incantation ritual against an "Adversary" (bèl dabābi, KAR 171), incantations and ritual actions against a "Curse" (māmītu, KAL 10 no. 5), and a long and unpublished namburbi-ritual against another type of curse (arratu, $\mathrm{N}_{4}$ no. 224, see Section 6.4.2). ${ }^{12} K A L 10$ no. 1 provides incantation incipits and ritual instructions as guidelines for performing a long ritual against a "Curse". The text therefore appears similar in scope to the šamallû manuscript $\mathrm{N}_{4}$ no. 175 and the mašmaššu manuscript KAR 298. Note that the text contains a number of erasures (rev. 3, 4, 5', 7', 27'). N4 no. 228 is a unique text with a previously unattested Sumerian-Akkadian bilingual incantation for washing the mouth (KA LUH) on a statue of the king made from various materials. Finally, BAM 307 was likely a scholastic manuscript containing the right side of a commentary-like text, as discussed below.

8 Birrat ìn̄, see Fincke 200o: 90-91.

9 The tulimu/tulimmu (CAD T: 124-25) designates the "spleen" or perhaps "pancreas"(?). See Westenholz 2010 for a discussion. Regarding the initial diagnosis in $B A M 78$, see also a commentary related to the Ugu series, 11N-T4, in Civil 1974: 336-37 line 6.

$10 B A M 121$ may have opened with prescriptions for the head, temples or the epigastrium, obv. 1: DIŠ NA SAG [...]/SAG.[KI ...]/SAG [ŠÀ ...] etc.

$11 B A M 333, L K A$ OO and $\mathrm{N}_{4}$ no. 228(?). BAM 333 is broken and may have contained a ritual instruction, and $\mathrm{N}_{4}$ no. 228 remains unpublished.

12 According to Frankena (1960: 174) several lines in the ritual can be found in parallel passages in Šurpu tablet 3 and 8. However, the relevant lines in Šurpu concern māmītu-curse. It is possible that AMC line 87 had to do with arratu lemuttu (Steinert 2018d: 256). 
TABLE 12 Texts without Kișir-Aššur's professional title

\begin{tabular}{|c|c|c|c|}
\hline Group & Text & Content & $\begin{array}{l}\text { Format and } \\
\text { description }\end{array}$ \\
\hline \multirow[t]{4}{*}{ Medical texts } & $B A M 9$ & (See Sections 3 and 5.4) & \\
\hline & $B A M 78$ & $\begin{array}{l}\text { Obverse: two prescriptions against a } \\
\text { hurting spleen (țlimu) where the } \\
\text { patient cannot sleep, his body has a } \\
\text { fever, he eats and drinks increasingly } \\
\text { less and he continually seeks out } \\
\text { Marduk's sanctuary (obv. 1-3, 7) where } \\
\text { the patient on an empty stomach is to } \\
\text { suck down a liquid (obv. 1-6) or eat a } \\
\text { remedy (obv. } 7-9 \text { ) } \\
\text { Reverse: one prescription (rev. 10-17) }\end{array}$ & Portrait; $[\ldots]$ \\
\hline & $B A M 121$ & $\begin{array}{l}\text { Obverse: ten prescriptions against the } \\
\text { upper (sAG) [...] (obv. 1-3(?), 4, } 5,6 \text {, } \\
7,8 \text { ) and a man's feet (obv. 9, 10-11), } \\
\text { which are specified later to be swollen } \\
\text { (obv. 11, 12); several prescriptions are } \\
\text { anointed (obv. 4, 5, 6, } 7 \text { ) or applied as a } \\
\text { poultice (obv. 13) } \\
\text { Reverse: two prescriptions treating a } \\
\text { man's feet (rev. 14) and feet swollen } \\
\text { with fever (rev. 18) to be applied as a } \\
\text { poultice (rev. 23) }\end{array}$ & $\begin{array}{l}\text { Landscape; } \\
\text { țppu }\end{array}$ \\
\hline & $B A M 131$ & $\begin{array}{l}\text { Obverse: two longer prescriptions } \\
\text { treating a patient ill with šaššațu (obv. } 1 \\
\text { and one whose eyes(?) are dried up, who } \\
\text { trembles on repeated occasions } \\
\text { and is scared or farts(?) (obv. 9-1o); } \\
\text { the first involves an innkeeper and later } \\
\text { washing and anointing the patient (obv. } \\
\text { 1-8), the other applying a substance } \\
\text { from the neck to the shoulder blades, } \\
\text { fumigating(?) the patient's bed and } \\
\text { washing the patient (obv. 9-15) } \\
\text { Reverse: three prescriptions for } \\
\text { bandages against winter stiffness }\end{array}$ & $\begin{array}{l}\text { Portrait; } \\
\text { [tuppu?] }\end{array}$ \\
\hline
\end{tabular}


TABLE 12 Texts without Kișir-Aššur's professional title (cont.)

$\begin{array}{lll}\text { Group Text } \quad \text { Content } & \begin{array}{r}\text { Format and } \\ \text { description }\end{array}\end{array}$

\begin{tabular}{|c|c|c|c|}
\hline & & $\begin{array}{l}\left.\left.\text { (rev. } 1^{\prime}-3^{\prime}\right) \text {, regular stiffness (rev. } 4^{\prime}-6^{\prime}\right) \\
\left.\text { and to soften up stiffness (rev. } 7^{\prime}-8^{\prime}\right)\end{array}$ & \\
\hline & $B A M 35^{1}$ & Obverse: (broken) & Portrait; N/A \\
\hline & & Reverse: a single prescription divided & \\
\hline & & into two entries (rev. $1-6,7-12$ ) listing & \\
\hline & & stones, which are threaded onto & \\
\hline & & plaited red wool and bound around the & \\
\hline & & left hand of the patient against an eye & \\
\hline & & illness (bir-rat IGI $\left.\mathrm{II}^{\mathrm{II}}\right)$ & \\
\hline Ritual texts & BAM 333 & Obverse: a fragmentary incantation & Portrait(?); N/A \\
\hline & & (obv. $1-8+[\ldots]$ ) mentioning Ea having & \\
\hline & & established the (healing) plant(s) & \\
\hline & & in the netherworld(?) & \\
\hline & & Reverse: fragmentary, only colophon & \\
\hline & & preserved (rev. 1'-4') & \\
\hline & $K A L 10$ & Obverse: ritual instructions for & Portrait(?); [...] \\
\hline & no. 1 & performing libations, applying & \\
\hline & & remedies to the patient and a figurine & \\
\hline & & of the "Curse" (obv. 1'-18') and other & \\
\hline & & actions $\left(22^{\prime}-24^{\prime}\right)$, as well as incantation & \\
\hline & & incipits with brief ritual instructions & \\
\hline & & $\left(19^{\prime}, 20^{\prime}, 21^{\prime}, 25^{\prime}\right)$ & \\
\hline & & Reverse: incantation incipits with brief & \\
\hline & & ritual instructions (rev. 1', 2', 3', 4', 5'-6', & \\
\hline & & 7', 8, 9', 10'-11, 12, 13, 14'-15, 16', & \\
\hline & & $\left.17^{\prime}-18^{\prime}, 19^{\prime}, 20^{\prime}-21^{\prime}\right)$, ritual instructions & \\
\hline & & for the patient (rev. 22'-23') and for & \\
\hline & & dealing with a figurine of the "Curse" & \\
\hline & & in order to release evil (rev. $\left.24^{\prime}-27^{\prime}\right)$ & \\
\hline & $K A L 10$ & Obverse and reverse: diagnostic state- & Portrait; tuppu \\
\hline & no. 5 & ment and ritual instruction (obv. 1-11), & \\
\hline & & fragmentary incantations (obv. 12-13, & \\
\hline & & 14-(breaks off), rev. 1'-3', 5'-10'), & \\
\hline & & fragmentary ritual instructions (rev. 4', & \\
\hline & & $\left.11^{\prime}\right)$ and a rubric (rev. 12') & \\
\hline
\end{tabular}


TABLE 12 Texts without Kișir-Aššur's professional title (cont.)

\begin{tabular}{|c|c|c|c|}
\hline Group & Text & Content & $\begin{array}{l}\text { Format and } \\
\text { description }\end{array}$ \\
\hline & KAR 21 & $\begin{array}{l}\text { Obverse: two incantations against } \\
\text { seeing dead people (obv. } 1-13,18-24) \\
\text { and a ritual instruction (obv. 14-17) } \\
\text { Reverse: one incantation (rev. } 7-18 \text { ) } \\
\text { and a ritual instruction (rev. } 1-6), \\
\text { presumably against the same problems }\end{array}$ & Portrait; N/A \\
\hline & $K A R 171$ & $\begin{array}{l}\text { Obverse and reverse: diagnosis } \\
\text { concerning an adversary bēl dabābi } \\
\text { (obv. 1-3) and a ritual instruction with } \\
\text { built in words to be spoken (obv. } 4^{-} \\
\text {rev. } 18 \text { ) }\end{array}$ & $\begin{array}{l}\text { Landscape; } \\
\text { N/A }\end{array}$ \\
\hline & KAR 267 & $\begin{array}{l}\text { Obverse: diagnoses for ghost and } \\
\text { confusional states (obv. 1-2), prayers } \\
\text { for Šamaš (obv. 12-26) and Girra } \\
\text { (obv. } 27-30 \text { ) and ritual instructions } \\
\text { (obv. } 3^{-11,31-38)} \\
\text { Reverse: incantation (rev. 1-24) }\end{array}$ & Portrait; tuppu \\
\hline & $L K A 40$ & $\begin{array}{l}\text { Obverse (fragmentary) and reverse: } \\
\text { šu'illa-prayer for Tašmētum (rev. 1'-8') }\end{array}$ & Portrait; tuppu \\
\hline & $\mathrm{N}_{4}$ no. 224 & $\begin{array}{l}\text { Obverse and reverse: namburbi-ritual } \\
\text { against various types of "curses" (arratu) } \\
\text { (obv. } 1-3 \text { ) consisting of incantations } \\
\text { and prayers (obv. 10-14, 16-17, 20-26, } \\
27-6 \text { o+rev. 1-17), a rubric (rev. 18), as } \\
\text { well as ritual instructions (obv. 4-9, 15, } \\
18-19 \text {, rev. 19-21, 22(?), 23-30) }\end{array}$ & Portrait; tuppu \\
\hline & $\mathrm{N}_{4}$ no. 228 & $\begin{array}{l}\text { Obverse and reverse: Sumerian- } \\
\text { Akkadian bilingual recitation for } \\
\text { performing mouth washing of a statue } \\
\text { depicting the king made from various } \\
\text { materials (obv. 1-rev. 9'). The text ends } \\
\text { with a rubric (rev. 10'11') }\end{array}$ & Portrait; N/A \\
\hline Other texts & $B A M 307$ & $\begin{array}{l}\text { Obverse: (broken) } \\
\text { Reverse: commentary-like explanatory } \\
\text { text (rev. } 1-27 \text { ) }\end{array}$ & Portrait; [...] \\
\hline
\end{tabular}


Noticeably, KAR 267 is the only dated text among Kișir-Aššur's tablets. The text contains a date formula dating it to the gth of the month Ulülu (AugustSeptember) in 658 вСЕ. ${ }^{13}$ As this tablet is the only one of Kișir-Aššur's texts that can be isolated to a specific moment in time, it is crucial to discuss $K A R$ 267 in relation to Kișir-Aššur's career (see Section 7.5).

\subsubsection{Text-internal Features Useful as Allocating Criteria}

Several features within the texts and their colophons can be used to argue for a distribution of the texts in Table 12 to career phases. Nine tablets contain a purpose statement similar to several of Kișir-Aššur's mašmaššu and mašmaš bit Aššur tablets ${ }^{14}$ and they probably served a similar purpose. BAM 307 also states that someone other than Kișir-Aššur copied this tablet at the request of Kișir-Aššur, which is a feature only found among his šamallû șehru, mašmǎ̌šu, and mašmaš büt Aššur tablets. ${ }^{15}$

Considering that Kiṣir-Aššur did not copy prescriptions in attested tablets between his šamallû șehru- and mašmaššu șehru-phase, several of the tablets above may belong to the earliest or later phases based on their content. However, this remains speculative. Namburbi-rituals are not attested with certainty before Kișir-Aššur's mašmaššu-phase, and N4 no. 224 may therefore belong to this or subsequent phases (see Section 6.4.1). Furthermore, KișirAššur's texts related to the palace or the Aššur cult can be argued to originate in his mašmaššu- or mašmaš bìt Aššur-phases (see Sections 7.3.1 and 8.6). Thus, it seem plausible that the ritual $\mathrm{N}_{4}$ no. 228 for washing the mouth of a statue of the king himself would belong to one of these phases. Regardless, there are tablets without titles, which seem to resemble tablets copied by Kișir-Aššur as šamallû șehru, such as the šu'illa-prayer copied on $L K A$ 40. ${ }^{16}$ However, the addition of a purpose statement in the case of $L K A 40$ argues against assigning this text to Kișir-Aššur's earlier phases. ${ }^{17}$

13 Maul 2010a: 205.

14 These tablets are: $B A M 78, B A M 121, B A M 333, B A M 351, K A L$ 10 no. 1, KAR 21, KAR 171, LKA 40, N4 no. 228.

15 One of Kișir-Aššur's mašmaššu-phase tablets was likely copied by another well known N4 individual, Aššur-šākin-šumi, and is published as the tablet KAL 4 no. 7 (see Maul 2O1oa: 216; Section 6.4). For a recently published tablet from the hand of Aššur-šākin-šumi, see Fadhil 2018.

16 The šu'illa-prayer $L K A 40$ was copied without a ritual and directed towards Tašmētum (Frechette 2012: 263, 273). The tablet layout and text are similar to Kiṣir-Aššur's LKA 43 copied as šamallû șehru.

17 Other examples from $\mathrm{N}_{4}$ of prayers for preparation of a ritual contain the names of the patient, e.g., LKA 51. However, the majority of such tablets do not contain a colophon (Maul 2010a: 213 note 82). 
At least $B A M 9$ seems to be from Kișir-Aššur's šamallû șehru-phase as argued in Section 5.4. Both BAM 9 and BAM 121 contain the ša Nabû tuklassu-phrase, and $B A M 121$ also contains a purpose statement. As discussed in Section 5.4, the ša Nabû tuklassu-phrase was an addition that Kișir-Ǎ̌šur, according to present evidence, added to tablets during his šamallû șehru- and šamallû mašmaššu șehru-phases. It is therefore possible that $B A M 9$ and $B A M 121$ were copied at this time. ${ }^{18}$ If this is correct, $B A M 121$ would be the earliest tablet with a purpose statement copied by Kișir-Aššur, and furthermore it would have been copied before his mašmaššu-phase while including medical prescriptions, which are otherwise not observed in the šamallû and šamallû mašmaššs șehru phases. The assignment of $B A M 121$ thus remains uncertain.

\subsection{Tablets with Broken Colophons}

A group of seven tablets contain breaks in the colophon and consequently these texts cannot be attributed to a specific career phase, regardless of whether or not the colophon originally contained a title. An additional 11 texts contain breaks in the names, preventing their distribution between Kiṣir-Aššur or KișirNabû. However, all these texts are listed in what follows to enable the fullest possible overview of texts that may be attributed to Kișir-Aššur. Furthermore, several of these texts contain features that are useful for distributing them to phases of Kișir-Aššur's career.

The diagnostic-therapeutic texts concern illnesses affecting the respiratory system and the arms (BAM 40), various types of stiffness, muscle and internal illnesses $(B A M$ 68), various demons affecting the state of mind and epigastrium or abdomen (BAM 311), insanity (BAM 202), witchcraft (BAM 206), and a text for making a patient drunk or thirsty (BAM 260), possibly aimed at improving the effect of alcohol and alleviating pain in connection to medical procedures (Scurlock and Andersen 2005: 361; Geller and Cohen 1995: 1813 and note 26). Noticeably, BAM 202 concerns various symptoms of insanity and the manuscript contains a previously unnoticed elaborate drawing of a demonic figure (Arbøll 2019).

The incantations and rituals concern a demon or ghost ( $K A L 4$ no. 37), a "Curse" (KAL 10 no. 13), some part of the ritual bit mèseri ( $\mathrm{N}_{4}$ no. 254), ritual instructions accompanying incantations for appeasing an angry god (ilì ul ìde, "My god, I did not know"; KAR 90; Lambert 1974), transgressions (KAL 9 no. 41),

18 Kișir-Aššur's šamallû manuscript N4 no. 175 is also the only text besides $B A M$ 121, which contains the writing PZÚ.KEŠDA-AN.ŠÁR/d aš-šur of his name. 
TABLE 13 Texts with broken colophons

\begin{tabular}{lll} 
Group Text Content & $\begin{array}{r}\text { Format and } \\
\text { designation }\end{array}$ \\
\hline
\end{tabular}

Kișir-Aššur [broken title/no title]

\begin{tabular}{|c|c|c|c|}
\hline Medical texts & BAM 40 & $\begin{array}{l}\text { Obverse: five preserved } \\
\text { prescriptions (obv. 1-6, } 7-11 \text {, } \\
\left.15^{-17}, 18-21+[\ldots]\right) \text { for } \\
\text { treating someone who is ill } \\
\text { (obv. 1), a slackening chest with } \\
\text { swelling and continually twitching } \\
\text { and standing(?) eyes infused with } \\
\text { blood (obv. 12-14, cf. obv. 15), or } \\
\text { grinding lungs (obv. 18). All } \\
\text { application methods are largely } \\
\text { broken } \\
\text { Reverse: four preserved } \\
\text { prescriptions (rev. 1'-5', 6'-9', } \\
\left.\text { 10'-12', } 13^{\prime}-17^{\prime}\right) \text {, two of which } \\
\text { are relatively broken but concern } \\
\text { problems in the left (rev. 10'-12') } \\
\text { and right arm (rev. 13') }\end{array}$ & Portrait; țuppu \\
\hline \multirow[t]{3}{*}{ Ritual texts } & $K A L 7$ no. 24 & $\begin{array}{l}\text { Obverse: two incantations for } \\
\text { gaining an audience (É.GAL.KU } 4 \text {. } \\
\text { RA) (obv. 1-9, 12-15) and at least } \\
\text { one ritual instruction (obv. 1O-11) } \\
\text { Reverse: at least one incantation } \\
\text { for gaining an audience (É.GAL. } \\
\mathrm{KU}_{4} \text {.RA) (rev. 1'-4') and a ritual } \\
\left.\text { instruction (rev. } 5^{\prime}-7^{\prime}\right)\end{array}$ & Portrait; u'iltu(?) \\
\hline & $K A L 10$ no. 13 & $\begin{array}{l}\text { Obverse: fragmentary diagnostic } \\
\text { statement and ritual instruction } \\
\text { for treating a "Curse" (obv. 1-12) } \\
\text { Reverse: fragmentary ritual } \\
\text { instruction(?) (rev. 4'-5') }\end{array}$ & Portrait(?); u’iltu \\
\hline & LKA 137 & $\begin{array}{l}\text { Obverse: prayer to Šamaš for } \\
\text { taking an omen with two stones } \\
\text { (obv. 1-29) }\end{array}$ & Portrait(?); u’iltu \\
\hline
\end{tabular}


TABLE 13 Texts with broken colophons (cont.)

\begin{tabular}{|c|c|c|c|}
\hline Group & Text & Content & $\begin{array}{l}\text { Format and } \\
\text { designation }\end{array}$ \\
\hline & & $\begin{array}{l}\text { Reverse: three columns with a } \\
\text { ritual instruction for making the } \\
\text { stone omen as well as a diagram for } \\
\text { how to cast the stones }\end{array}$ & \\
\hline & $\begin{array}{l}\text { (N4 no. 254, } \\
\text { unpublished) }\end{array}$ & (Bīt mēseri?) & (Uncertain) \\
\hline \multirow[t]{2}{*}{ Other texts } & $\mathrm{N}_{4} \mathrm{~A}_{2362}$ & (Unclear due to damage) & $\begin{array}{l}\text { (Fragmentary); } \\
{[\ldots]}\end{array}$ \\
\hline & $\begin{array}{l}\text { (N4 no. 401, } \\
\text { unpublished) }\end{array}$ & (Literary?) & (Uncertain) \\
\hline
\end{tabular}

Kișir-[Aššur/Nabû + broken title/no title]

\begin{tabular}{|c|c|c|c|}
\hline \multirow[t]{2}{*}{ Medical Texts } & $B A M 68^{\mathrm{a}}$ & $\begin{array}{l}\text { Obverse and reverse: one pre- } \\
\text { scription for someone who is ill } \\
\text { with šibit šāri, himit șēti, šimmatu, } \\
\text { ri[mûtu], šaššațu, "Hand of ghost", } \\
\text { "Hand of Curse", or any illness, and } \\
\text { the prescription is to be issued as } \\
\text { an enema (obv. 1-rev. 17) }\end{array}$ & Landscape; $[. .]$. \\
\hline & $B A M 202$ & 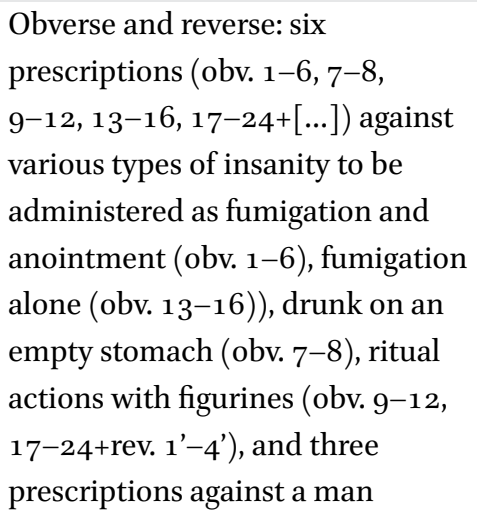 & Portrait; N/A \\
\hline
\end{tabular}

a Maul (2019: 287) notes that the tablet upon collation can be distributed to Kișir-Aššur and likely assigned to his mašmaššu-phase. However, he transliterates PKi-șir-AN.[ŠÁR MAŠ. MAŠ(?)]. I have therefore chosen to designate $B A M \quad 68$ as a tablet copied by either Kiṣir-Aššur or Kișir-Nabû during an uncertain phase. 
TABLE 13 Texts with broken colophons (cont.)

$\begin{array}{lll}\text { Group Text Content } & \begin{array}{l}\text { Format and } \\ \text { designation }\end{array}\end{array}$

\begin{tabular}{|c|c|c|c|}
\hline & & $\begin{array}{l}\text { suffering from "Hand of bennu" } \\
(\text { rev. 5'-11', 12', 13') all supplying } \\
\text { him with neck amulets }\end{array}$ & \\
\hline & $B A M 206$ & $\begin{array}{l}\text { Obverse: (broken) } \\
\text { Reverse: a single prescription of } \\
\text { various ingredients to be drunk } \\
\left.\text { on an empty stomach (rev. } 1^{\prime}-15^{\prime}\right)\end{array}$ & $\begin{array}{l}\text { Portrait; } \\
\text { IM.GÍD.DA }\end{array}$ \\
\hline & $B A M 26 \circ$ & $\begin{array}{l}\text { Obverse/reverse(?): six } \\
\text { prescriptions, likely all for } \\
\text { drinking, to make a man drunk } \\
\left.\text { (obv. } 1-3,4,5^{-6}\right) \text {, to make a man } \\
\text { thirsty (obv. } 7-10 \text { ) and related to } \\
\text { a coughing man (obv. 12-15) }\end{array}$ & Portrait; u'iltu \\
\hline & $B A M 311$ & $\begin{array}{l}\text { Obverse: } 41 \text { prescriptions (obv. } \\
\text { '-5o') for producing mêlu neck } \\
\text { amulets against hūṣ hūp }(i) \text { libbi, } \\
\text { Lugal-urra, mimma lemnu, and } \\
\text { the alû-demon } \\
\text { Reverse: at least } 26 \text { prescriptions } \\
\text { (rev. 51'-93') for producing mêlu } \\
\text { neck amulets treating a terrified } \\
\text { man crying like a goat in his bed, } \\
\text { a man crying out, Antašubba, } \\
\text { Lugal-urra, and a man grinding } \\
\text { his teeth in bed }\end{array}$ & Portrait; N/A \\
\hline tual texts & $K A L 4$ no. $37^{\mathrm{b}}$ & $\begin{array}{l}\text { Obverse (fragmentary): remains } \\
\text { of a ritual instruction (obv. 1'-9') } \\
\text { and a prayer(?) (obv. 10'-14') } \\
\text { Reverse (fragmentary): remains of } \\
\text { a ritual instruction (rev. 1'-6') }\end{array}$ & Portrait(?); [...] \\
\hline
\end{tabular}

b Maul and Strauß (2011: 85-86) reconstruct this text as Kișir-Nabû's, presumably based on the fact that both broken ancestor names carry the title mašmaš bìt Aššur. In Kișir-Aššur's colophons, the last ancestor, Bāba-šuma-ibni, would normally be zabardabbi Ešarra, whereas both Kișir-Nabû's ancestors are frequently mašmas bīt Aššur. However, in Kișir-Aššur's LKA 119 from his mašmaš büt Aššur-phase, he provides the mašmaš büt Aššur title for his father and grandfather. Therefore, the name cannot be reconstructed with certainty. 
TABLE 13 Texts with broken colophons (cont.)

\begin{tabular}{|c|c|c|c|}
\hline Group & Text & Content & $\begin{array}{l}\text { Format and } \\
\text { designation }\end{array}$ \\
\hline & $K A L 9$ no. $41^{\mathrm{c}}$ & $\begin{array}{l}\text { Obverse and reverse(?): } \\
\text { fragmentary prayer to various } \\
\text { gods concerning transgressions } \\
\text { (obv. 1-9+ rev. 1'-2') and a ritual } \\
\text { instruction (rev. 3') }\end{array}$ & $\begin{array}{l}\text { (Fragmentary, } \\
\text { Portrait(?)); N/A }\end{array}$ \\
\hline & $\mathrm{N}_{4}$ no. 443 & $\begin{array}{l}\text { Obverse and reverse: prayer to } \\
\text { Girra(?) }\end{array}$ & Portrait(?); N/A \\
\hline & KAR 90 & $\begin{array}{l}\text { Obverse and reverse: header } \\
\text { stating the content is related to } \\
\text { the ritual actions of ili } u l \bar{\imath} d e(\mathrm{obv} \text {. } \\
\text { 1), thereafter follows one long } \\
\text { ritual instruction (obv. } 2-\text { rev. } 15 \text { ) } \\
\text { and four brief ones (rev. 16, 17, 18, } \\
\text { 19); the final line states that the } \\
\text { ritual actions of Šurpu are per- } \\
\text { formed afterwards (rev. } 20 \text { ) }\end{array}$ & Portrait; N/A \\
\hline \multirow[t]{2}{*}{ Other texts } & ACh Supp. 224 & $\begin{array}{l}\text { Obverse and reverse (broken } \\
\text { around the middle): commentary } \\
\text { on individual lines of at least the } \\
\text { 2oth tablet of the astrological- } \\
\text { astronomical omen series Enūma } \\
\text { Anu Enlil }\end{array}$ & Portrait; malsûtu \\
\hline & BAM 366 & $\begin{array}{l}\text { Obverse (col. i-ii) and reverse } \\
\text { (col. iii-iv): list containing various } \\
\text { types of stones and how many are } \\
\text { in the collection; runs from highest } \\
\text { to lowest number and produces a } \\
\text { total of the inventory }\end{array}$ & $\begin{array}{l}\text { Two-columned; } \\
{[\ldots]}\end{array}$ \\
\hline
\end{tabular}

c Jakob (2018: 91) reconstructs the name as Kișir-[Aššur] in rev. 4' and the title [mašmaš bìt $A$ ššr ] in rev. 5'. Such a division of name and title across two lines is attested in, e.g., BAM 164 and $B A M 177$, although I avoid restoration in $K A L 9$ no. 41 as nothing indicates that a title was written in rev. 5'. 
incantations and instructions in preparation of going to an audience in a palace (KAL 7 no. 24; Stadhouders 2013: 305-11), and a prayer to a divinity who may have been Girra (N4 no. 443). Furthermore, LKA 137 consists of a prayer, a ritual and an illustrative drawing for preparing a stone omen ritual (psephomancy). ${ }^{19}$

Additionally, there are three texts that cannot be categorized properly within the previous groups: an unpublished literary extract or text (N4 no. 4O1), a slim two-columned list of amulet stones with designations in the margins of the number available within the collection (BAM 366; Schuster-Brandis 2008: 189f. with notes, 218 note 512), and ACh Supp. 224 from Nineveh that provides a commentary on the first paragraph of the 2oth tablet of Enüma Anu Enlil concerning eclipses (Rochberg 1988: 176, 225-27; see Section 7.6). $\mathrm{N}_{4} \mathrm{~A} 2362$ is presumably too broken to determine the content.

\subsubsection{Text-internal Features Useful as Allocating Criteria}

Several of the tablets discussed above cannot be attributed to a career phase with any certainty, and must be classified as tablets written by either Kișir-Aššur or Kișir-Nabû at an uncertain stage of their career ${ }^{20}$ Other texts can be argued to stem from certain phases based on text-internal features. As in the group without titles, a number of the tablets with broken colophons include purpose statements that enable a distribution to later career phases. ${ }^{21}$ Similarly, $B A M$ 206 was labelled as an IM.GÍD.DA, which were only used during Kișir-Aššur's šamallû mašmaššu șehru- and mašmaššu-phases in the surviving evidence.

$K A L 7$ no. 24 likely had a broken title after Kișir-Aššur's name. Meinhold (2017: 62) reconstructed his title as [MAŠ.MAŠ], and it is relatively certain that the tablet cannot have contained more than two broken signs (ibid.: 164-65, 194-95). The content concerns "entering the palace" (É-gal-ku ${ }_{4}-\mathrm{ra}$ ) and such incantations generally focus on how to get access to legal authorities and averting any dangers by doing so (Stadhouders 2013: 305-11; see Stadhouders and Panayotov 2018 for similar texts from $\mathrm{N}_{4}$ ).

Considering that rituals against an "Adversary" ( $b \bar{e} l$ dabābi), be it magically or legally, appear on a tablet without a title (KAR 171) that also contains a purpose statement, and that such legal connotations are found associatively through

19 Lambert 2007: 19-20; Finkel 1995; Horowitz and Hurowitz 1992; cf. Reiner 196oa. LKA 137 obv. 29: [K]A.INIM.MA EŠ.BAR ${ }^{\text {na4 GIŠ.NU }}{ }_{11}$ GAL na4KUR.NU.[DIB], "Incantation for an oracle (using) alabaster and haemati[te] stones" (Finkel 1995: 272).

20 Kișir-Aššur's broken unassigned texts: $B A M$ 4O, N4 no. 401. Broken unassigned texts from either Kișir-Aššur or Kișir-Nabû: BAM 26o, KAL 4 no. 37, KAR 9o.

21 The broken tablets with purpose statements are: $B A M$ 68, BAM 202, BAM 311, KAL 9 no. 41, $K A R 9$ 9, $\mathrm{N}_{4}$ no. 443. It is unclear if the intitial line in the colophon of $B A M 206$ is a purpose statement, see Ch. 8 note 84 . 
"Seizing-of-the-mouth" kadabbedû in Kiṣir-Aššur's BAM 28 from his mašmaš bit $A$ ššrur-phase, it is likely $K A L 7$ no. 24 stems from at least his mašmaššu-phase. ${ }^{22}$ However, it is unclear if $K A L 7$ no. 24 was designed to grant Kiṣir-Aššur himself or his clients an audience. ${ }^{23}$

Other texts provide clues for their distribution as well. Section 6.3 discusses the use of house demarcating rituals during Kișir-Aššur's mašmaššu-phase. Therefore, the text relating to bit mèseri ( $\mathrm{N}_{4}$ no. 254) may belong to KișirAššur's mašmaššu-phase, although he also copied guidelines for this ritual as šamallû ( $\mathrm{N}_{4}$ no. 175). Kișir-Aššur's ritual for obtaining a stone omen $L K A 137$ is listed in the first section of the EM. ${ }^{24}$ However, it is uncertain during what phase Kișir-Aššur copied the text, although the content was copied from a certain Nabû-[...]'s IM.GÍD.DA, possibly pointing towards Kișir-Aššur's šamallûu mašmǎ̌šu șehru- or mašmaššu-phase. ${ }^{25}$ The commentary ACh Supp. 224 is discussed in Section 7.6.

\subsubsection{Excursus: Inventory Texts from the $\mathrm{N}_{4}$ Collection}

$B A M 366$ is a two-columned list of amulet stones wherein each entry is marked with a number, which possibly indicates how many stones were present in the stock taker's collection (Schuster-Brandis 2008: 189f. with notes). Unfortunately, the colophon is too broken to determine if the tablet was written by Kișir-Aššur or Kișir-Nabû, and whether or not it contained a title. I have chosen to discuss this manuscript here alongside two similar texts in relation to Kiṣir-Aššur's tablets without titles or with broken colophons.

It remains uncertain if $B A M 366$ was written at some stage of apprenticeship, in which the apprentice took note while his father took stock, or if the stock taker was a fully educated specialist. The text likely lists the stones and numbers available at a specific point in time. In total, the list states that the $\mathrm{N}_{4}$ collection included 315 stones (BAM 366 rev. 18'), divided into many types, and there were as many as 14 stones of some types (BAM 366 obv. 5). The colophon totals the entire tablet and states:

\footnotetext{
22 Note that kadabbedû was also treated in Kișir-Aššur's šamallû șehru manuscript BAM 201.

23 Kișir-Aššur was likely not involved in the Aššur cult before he became mašmaš bìt Aššur (Section 8.1). If KAL 7 no. 24 was designed to grant him entrance to, e.g., the palace and the king, the text may have belonged to his late mašmǎšsu-phase, as this use of the text would indicate he was partially involved in rituals pertaining to the state during this phase.

24 KAR 44 rev. 25: "(Omen) decision by stars, birds, oxen, goats (and) stone oracular utterance of all god(s)", EŠ.BAR MUL.MEŠ MUŠEN.MEŠ $u$ GU $_{4}$.MEŠ MÁŠ.ANŠE.MEŠ INIM.GAR ${ }^{\text {na4DÚR.NA.DE }}{ }_{5}$ DINGIR.DÙ.A.BI. 
A total of 315 stones (for) 'neck-(amulet(s))' of Marduk, which are suitable for use, placed $\left[i n^{?} . ..\right]$, the tablets $[\mathrm{x}(?)]$ Kiṣir-[Ǎšur $/$ Nabû ....$^{26}$

As discussed in Section 7.4, the tablets with purpose statements must have been used in relation to preparing rituals. If so, practical application must have required access to the material prescribed in the texts. Comparable sources from other periods illustrate that specific (prepared) drugs could be kept in jars upon which the name of the malady it cured was incised (Walker 1980). Inventory texts, such as $B A M 366$, may therefore reflect items kept in the $\mathrm{N}_{4}$ house at some point in the 7 th century. Although the few objects found in the $\mathrm{N}_{4}$ house cannot presently be connected to performative practices, $B A M 366$ and one additional text attest to these aspects of the family trade. ${ }^{27}$ Furthermore, a third text can be added, which illustrates that the family also had an interest in taking stock of texts.

The second text is KADP 36 . The manuscript was excavated in the $\mathrm{N}_{4}$ collection and does not contain a colophon (Pedersén 1986 N4 no. 136). This sixcolumned text lists an impressive 177 drugs whereof 159 are of vegetable origin (Böck 2011: 702). The tablet was likely organized to provide an overview of what medicaments were in store by giving running totals, and adding specific references to where the ingredients were located (Böck 2010d: 164). A few examples read: "[A total] (of) 15 (different) ingredients, (located) on the first wooden beam from above", and "A total of 17 (different) ingredients, (located) on the third wooden beam". ${ }^{28}$ Clearly, the owners of the $\mathrm{N}_{4}$ house kept track of their supplies and had the necessary medicaments to perform the rituals needed. ${ }^{29}$

26 BAM 366 col. iv 18'-22': PAP-ma 3 ME 15 NA 4 .MEŠ 19' GÚ šá ${ }^{\mathrm{P}(s i c)} M a r-d u k^{20^{\prime}}\left[\check{s}^{2}\right] a^{?}$ ana ŠU ${ }^{\mathrm{II}}$ šu-șu-u ${ }^{21}[(\mathrm{x}) \mathrm{x}]$ GAR-an DUB-pa-ni ${ }^{22^{\prime}}$ [x] ${ }^{\mathrm{P}}$ Ki-șir-[...] (Schuster-Brandis 20o8: 61-62 and note 172). For the translation of ša ana qāti šūșûu, see $C M A w R$ 2: 416 with further references; $C M A w R$ 1: 64, 121; Reiner 1961: 10 note 1; see discussion in Ch. 6 note 25. It seems likely that the DIŠ is a mistake for ${ }^{\mathrm{d} !}$ Mar-duk, possibly indicating a cultic context.

27 For the archaeological finds in N4, see Miglus 1996: 236-41.

28 KADP 36 col. i 18: [PAB] 15 ina gišPA 1 AN.[T]A-te (cf. CAD H: 155). See also col. i 36: [PA]B 20 ina gišsA 2-te. Col. ii 11: $\mathrm{PAB} 17$ ina gišPA $3^{-}$te. In col. iv 25 storage vessels are mentioned. The drugs are described as stored in the upper, second, third, etc. shelf (hattu), roasting vessel (qālìtu/karpat qalìte) or placed in bowls (qabūtu) (see Böck in press; Köcher 1955: 10). The term hațtu is commonly translated as "shelf" in relation to this text, although the term has a range of literal meanings, such as "sceptre, staff, stick, branch" (CAD H: 153). Therefore, Böck (in press) argues that hațtu should be translated into German as "stock", referring to wooden beams that likely provided support for the roof as part of the house. The various ingredients would possibly have been hung from these to dry. In lack of a better term, I translate it as "wooden beam" here.

29 A study of the correlation between both texts and the ingredients used in the $\mathrm{N}_{4} \mathrm{ritu}-$ als and prescriptions is beyond the scope of the present work, but is worthy of future 
A third text (VAT 13723+) from $\mathrm{N}_{4}$ lists various text series and their individual tablets by incipits, and in the margins the scribe presumably provided notes on the number of manuscripts kept in the collection (Geller 2000: 226ff., text A). As such, this text illustrates that multiple copies likely existed in the $\mathrm{N}_{4}$ collection of several tablets within a series, but that the users were perhaps not always aware of the numbers until they took stock (see Maul 2010a: 215 note 93 ). ${ }^{30}$

\subsection{The mašmaššu-phase and Purpose Statements}

Kișir-Aššur's mašmaššu tablet $L K A 115$ is the first tablet from a career phase that contains a purpose statement. However, such statements also occur in his mašmaš bit Ǎ̌šur-phase tablets and on tablets without titles. All these texts are discussed in what follows in order to argue why several of Kișir-Aššur's tablets without titles can be assigned to his mašmaššu- or mašmaš büt Aššur-phases. $L K A 115$ was also copied at the request of Kișir-Aššur (ú-šaš-țir-ma), and such tablets are also discussed as an allocating criterion.

This study refers to phrases expressed as ana șabāt epēši "for undertaking a (ritual) procedure" as purpose statements. ${ }^{31}$ In general, such phrases are especially attested in Assur and they are frequently coupled with statements that refer to the content as "quickly, hastily extracted" (hanțiš/zamarnasāhuu). ${ }^{32}$ This expression likely designates that the content of the tablet was copied in order to ensure the correct preparation and performance of a specific ritual

research. Equally interesting is the possible economic aspect of such ingredients, which also requires further investigation, but see preliminarily Myer 1975: 137ff.

Although the text is not a catalogue, as such, it does list numbers of individual texts of series in relation to the $\mathrm{N}_{4}$ collection (Schwemer 2017: 50-51; Koch 2015: 325; cf. Robson 2013: 56). See Section 3.6.1.

Couto-Ferreira 2018: 157, 162 and note 43; Maul 2010a: 212-13; Geller 2010: 100-101; Böck 20o8: 296; Maul 2003: 18o-81; Maul 1994: 159 note 16; Bottéro 1983: 159; Hunger 1968: 12; Leichty 1964: 153; Eilers 1933: 325. The phrase was typically written in either of the following ways: a-na/ana șa-bat/DAB e-pe-ši/DÙ-(ši). The individual phrase in Kișir-Aššur KAR 38 (mašmaš bit Aššur) differs slightly, but relates to the purpose of the text. KAR 38 rev. 41: a-na mu-še-piš-ú-ti ḩa-an-țiš ZI-[(ha?)]. Maul translates ana șabāt epēši as: "für die Durchführung des Rituals", "für die Durchführung/Anwendung (eines Rituals)", "für die Vorbereitung der Durchführung (der Behandlung)"; Couto-Ferreira: "in order to apprehend the procedure"; Geller: "for use"; Bottéro: "rapidement prises pour usage immediate"; Hunger: "für die Durchführung eines (bestimmten) Rituals"; Leichty: "for performance of the ritual". The use of the term "purpose statement" here differs slightly from the largely didactic and votive examples illustrated by Peace (1993).

32 The exact nuances of hanțiš and zamar/șamar in relation to nasāhu are difficult to evaluate. 
or treatment (Maul 2010a: 212-13, 216; Bottéro 1983:159; Hunger 1968: 12). ${ }^{33}$ However, the exact role of the tablet in relation to a ritual context cannot be specified. ${ }^{34}$ Contemporary letters corroborate that tablets were in fact copied in order to perform certain rituals:

I shall now look up, collect and copy numerous - 20 to 30 - canonical and non-canonical tablets, (but) perform (the prayers) (only) tomorrow evening and on the night of the $15^{\text {th }}$ day.

$S A A 10$ no. $240^{35}$

The quoted letter also suggests that relevant tablets could be copied quickly and in great quantity. ${ }^{36}$ Other letters from Nineveh suggest that several tablets with rituals were copied in their entirety as concrete instructions for some performances (Robson 2019: 118-119). When such tablets were quickly copied in preparation for a ritual, an assistant may have copied the tablet(s) needed for the ceremonial supervisor (see Section 6.1).

\subsubsection{Kișir-Aššur's Tablets with Purpose Statements}

A total of 19 tablets with a purpose statement can be assigned to Kișir-Aššur throughout his career, which can be divided into three groups: at least one text from Kiṣir-Aššur's mašmaššu-phase, eight texts from his mašmaš büt Aššur-phase, nine without a title, and and an additional text with a broken

33 The verb șabātu was also used to describe the actions associated with editorial activities. Esagil-kīn-apli's and Assurbanipal's editorial activities were described as SUR.GIBIL (= $z a r \hat{\text {, }}$ âru or șa-ra-a(?)) șabātu, understood literally as: " to undertake a new plying, spinning, weaving" and relates to the process of producing or receiving a "new edition" of a text (Frahm 2018a; Steinert 2018a: 66-72; Wee 2015: 254 and note 27; Wee 2012: 31-32, 3034; Frahm 2011a: 327-28; Rutz 2011: 294 and note 3; Heeßel 2010a: 143 note 11; Stol 2007b: 241-42; Finkel 1988: 148, [S]UR.GIBIL DAB.MEŠ-ma; Hunger 1968: 98-99, no. 321 line 3; see also this term in the AMC line 125; Geller 2018a: 46-47, 49ff.; Panayotov 2018b: 113; Steinert 2018c: 166ff.; Steinert 2018d: 277-278). Therefore, the verb șabātu here likely refers to the act, i.e., "to undertake work" (CAD Ș: 21,5). Thus, ana șabāt epēši becomes "for the execution of a specific performance" in $C A D$ (E: 195,1c1').

34 Some $\mathrm{N}_{4}$ tablets for preparation of rituals included the name of the patient, e.g., $L K A$ 51 without a colophon, and these examples indicate that such tablets played a concrete purpose in the ritual preparations (see Maul 2010a: 213 note 82).

35 SAA 10 no. 240 obv. 23-rev. 2 in Parpola 1993: 191. See also Maul 1994: 31-32, 34; SAA 10 no. 245 rev. 12-18 in Parpola 1993: 195.

36 The letter $S A A$ 10 no. 255 states that "the tablets are too numerous" to be copied in time for the ritual, which argues against the idea of quickly copying tablets in great quantity (Parpola 1993: 201-2). 
title. ${ }^{37}$ Furthermore, six texts written by either Kișir-Ǎšsur or Kișir-Nabû during uncertain career phases contain purpose statements. ${ }^{38}$ Generally, Kișir-Aššur's ana șabāt epēši tablets also contain a statement conveying that they were "(quickly) extracted", attesting to the urgency of their production. ${ }^{39}$

Section 6.2 suggested that Kișir-Aššur likely began supervising healing ceremonies during his mašmaššu-phase, when he copied KAR 23o. Additionally, namburbi-rituals seem to appear in his corpus of texts around this time, possibly indicating a connection. $L K A 115$ represents a namburbi-ritual with a purpose statement and stems from Kișir-Aššur's mašmaššu-phase. As a result, the purpose statements seem to designate that the tablet in question was copied when Kiṣir-Aššur was at a level at which he was allowed to supervise a ritual performance. By extension, he must have been around the level of mašmaššu. As discussed above, it is likely that writing his title on tablets was not always a necessity for Kișir-Aššur. However, he is assumed to have included it regularly until his mašmaššu-phase.

Maul (2010a: 213) commented on $\mathrm{N}_{4}$ tablets with purpose statements and emphasized: "Kein einziges dieser Manuskripte wurde von einem 'jungen Assistenten', einem 'Assistenten' oder einem 'assistierenden jungen Beschwörer' geschrieben". He adds that the reason was probably because it was the master's domain to provide the cure and that it was his responsibility to ensure that mistakes in the text did not induce fatal consequences. Maul's suggestion supports the hypothesis formulated here. ${ }^{40}$ In relation to this hypothesis, it is therefore noteworthy that Maul and Strauß (2011: 49) reconstructed the final line in Kișir-Aššur's šamallû șehru tablet KAL 4 no. 19 with a purpose statement:

37 Mašmaššu: LKA 115; mašmaš bīt Aššur: BAM 99, BAM 164, BAM 177, BAM 186, BAM 188, BAM 300, KAR 38 (see Ch. 8 note 84), KAR 374; without titles: $B A M$ 78, BAM 333, BAM 351, KAL 10 no. 1, KAR 21, KAR 171, LKA 40, N4 no. 228; without title, but including the ša Nabû tuklassu-phrase: $B A M$ 121; possibly broken title: $K A L 10$ no. 13. See Appendix 1. It remains uncertain if $K A R 298$ contained a purpose statement (cf. Wiggermann 1992: 41; Hunger 1968: 70 no. $201 \mathrm{~ms} \mathrm{I})$.

$38 B A M 68, B A M 202, B A M$ 311, $K A L 9$ no. $41, K A R$ 9o, N4 no. 443. It is unclear if the first line in the colophon of $B A M 206$ is a purpose statement, see Ch. 8 note 84 . For $B A M 68$, see Table 13 note a.

39 The phase is usually written (hanțiš/zamar) issuha/nasha (ZI-ha) or simply zamar before other statements (see Section 9.2).

40 The first of Kișir-Nabû's texts with this phrase also stem from his mašmaššu-phase (KAR 22, KAR 56). However, Maul (1994: 159 note 18) suggests that tablets with the hantiš nasha "hastily extracted" remark could also have been used to perform the ritual inscribed, although such tablets could also have been copied to enhance the collection (ibid.: 16o). In relation to a discussion of the šamallû șehru tablets that were "quickly" copied, Maul (2010a: 216) proposed that such tablets could have played a role in the preparation of the ritual. This remains uncertain. 
KAL 4 no. 19 rev. 8': [(ana șabāt epēši) hanțiš $]$ is-su-h̆a $a^{41}$

In my view, there is insufficient space on the tablet for this reconstruction. Considering the original size of the tablet, I doubt the line would have held more than four smaller signs before is-su-ha. ${ }^{42}$ Thus, I would suggest reconstructing [ha-an-țiš]. ${ }^{43}$ As a result, no surviving Kișir-Aššur colophon with a title indicates that purpose statements were used by Kișir-Aššur before he became mašmaššu. ${ }^{44}$

Following these hypotheses, the implication is that Kișir-Aššur would typically have copied tablets with purpose statements, but excluding titles, somewhere around his mašmaššu- or mašmaš bit Aššur-phases, likely after the implementation of KAR 230. This observation can be applied to the tablets with purpose statements in general, i.e., they are assigned to Kișir-Aššur's mašmaššu and mašmaš büt Aššur tablets. However, BAM 121 contains both the ša Nabû tuklassu-phrase as well as a purpose statement. ${ }^{45}$ Section 5.4 suggests that Kișir-Aššur used the ša Nabû tuklassu-phrase before he became mašmaššu șehru. Therefore, BAM 121 may have been the first purpose statement tablet copied by Kișir-Aššur before he became mašmaššu. This issue cannot be resolved.

\subsubsection{Tablets Copied on Behalf of Kișir-Aššur}

$L K A 115$, containing a ritual against any evil omen observed in a man's house, stems from Kișir-Aššur's mašmaššu-phase and it is also the first of three tablets from Kișir-Aššur's later phases that were likely copied by someone other than Kișir-Aššur, perhaps an assistant at some unknown career stage, ${ }^{46}$ and thereafter checked by Kișir-Aššur himself:

LKA 115 rev. 10': ki-ma la-bi-ri-šú šà-țir bà-[rì (x)]

LKA 115 rev. 11': a-na șa-bat e-pe-ši $\mathrm{P}^{\prime} \mathrm{Ki}$-șir-Ǎ̌s-šur MAŠ.MAŠ

LKA 115 rev. 12': 'ú̄-šaš-țir-ma íb-ri

41 Alternatively, they propose the reading ana mušêpišūti (Maul and Strauß 2011: 49). This possibility is also dismissed here.

42 I collated the tablet (VAT 14005) in Berlin during the summer of 2016.

43 Kișir-Aššur has several examples of colophons in which the last line only contains the phrase hanțiš/zamar nasāhuu, see BAM 81, BAM 186, BAM 188, BAM 333(?), BAM 351, LKA 43, LKA 89+(?).

44 Note again the problematic $B A M 121$ with a purpose statement, and possibly from before Kișir-Aššur's mašmaššu-phase (Section 5.4).

45 The tablet is labelled a țuppu, but it is the only one among Kișir-Aššur's țuppus that is in landscape format (see Appendix 1). Tablets with landscape format are only missing from Kiṣir-Aššur's šamallû-phase.

46 Maul 2010a: 216-17; Maul 1994: 32. 
Written (and) checked like its original. For undertaking a (ritual) procedure (of) Kișir-Aššur, the mašmaššu. He had someone copy (the text), and he checked (it).

The Š-stem of šațāru and G-stem of barû indicates that Kișir-Aššur had the content copied on his request and he checked it himself. Considering all of Kiṣir-Aššur's tablets, someone copied at least three further tablets on behalf of Kișir-Aššur: N4 no. 241 from Kișir-Aššur's šamallû șehru-phase, $B A M 307$ without a title, and BAM 99 from Kiṣir-Aššur's mašmaš bit Aššur-phase. ${ }^{47}$ While $\mathrm{N}_{4}$ no. 241 was argued in Section 3.7.3 to represent Kișir-Aššur's duties as a tutor during his earliest phase, both BAM 99 and $L K A 115$ contain mašmaššu and mašmaš bìt Aššur titles and they were provided with purpose statements, which, as argued above, are an indicator for a later career phase. ${ }^{48}$ These later texts likely attest to Kișir-Aššur being in a position in which junior assistants would aid him in the preparations (and performance?) of rituals. Additionally, $B A M 307$ can also be assigned to at least Kișir-Aššur's mašmaššu-phase on the basis of its content and the lack of a title (Section 7.6).

Whether the later texts copied on behalf of Kișir-Aššur also functioned as exercises for the younger copyist remains uncertain, although this seems to have been the case in $\mathrm{N}_{4}$ no. 241 (cf. Clancier 2014: 56). Nonetheless, it is noteworthy that Kișir-Aššur still labelled the text as his own and that it did not include the copyist's name. Based on the discussions above, it therefore seems unlikely that tablets without titles that include purpose statements should belong to Kișir-Aššur's earliest phases. Whatever tablets Kișir-Aššur may have copied for his father's performances are therefore not regarded here as being those with Kișir-Aššur's name and purpose statements.

\subsubsection{Purpose Statements and Notes on Breaks}

Kiṣir-Aššur copied at least three tablets with notes in the text stating that the original copied from contained breaks. Such notations appear as hepi/hipi "it is broken" or "break" as well as hepi/hīpi eššu "it is broken; new" or "new break" (Gabbay and Jiménez 2019:60; Monroe 2019; Clancier 2014: 53-55; Worthington

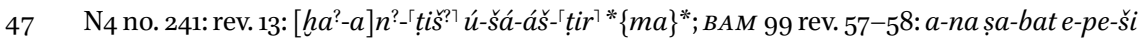
PKi-șir-Aš-šur MAŠ.MAŠ É Aš-šur ${ }^{8}$ za-mar ú-šaš-țir-ma íb-ri ...; BAM 307 rev. 28-29: [...] PKi-șir-AN.ŠÁR DUMU p.dPA-be-sún ${ }^{29}[$ [... ú-š] aš-țir-ma ib-ri. BAM 307 was not necessarily an ana șabāt epēši tablet, as the signs before Kișir-Aššur's name are broken.

48 No texts copied on behalf of Kișir-Nabû are known. Kișir-Nabû may not have reached the level mašmaš büt Aššur, perhaps because Assur fell to the Babylonians and Medes during his mašmaššu-phase, i.e., around 614 BCE (see Maul 2010a: 204, 209-11). See Section 2.3.3. 


\begin{tabular}{|c|c|c|c|}
\hline Text & Phase & Purpose/Label & Type of breaks \\
\hline \multicolumn{4}{|c|}{ Kișir-Aššur } \\
\hline BAM 99 & mašmaš bit Aššur & ana șabat epēši & Rev. 40 he-pí eš-šú \\
\hline$B A M 129$ & šamallû șehru & {$[\ldots]$} & Col. i 8, 10, 31 he-pí eš-šú \\
\hline $\mathrm{N}_{4}$ no. 237 & šamallû șehru & u'iltu & Rev. $6,7,8,(10$ ?) he-pí eš-šú \\
\hline \multicolumn{4}{|c|}{ Kișir-Nabû } \\
\hline BAM 33 & mašmaššu șehru & {$[\ldots]$} & Obv. 7, 9, 11 he-pí \\
\hline KAR 44 & {$[\cdots]$} & u'iltu & Obv. 21 he-pí eš-šú \\
\hline KAR $5^{6}$ & mašmaššu & ana șabat epēši & Obv. 7', 8', 10' he-pí eš-šú \\
\hline \multicolumn{4}{|c|}{ Kișir-[Aššur/Nabû] } \\
\hline$B A M 311$ & (No title) & ana șabat epēši & Obv. $26^{\prime}, 31^{\prime}$, rev. $73^{\prime}, 75^{\prime}$ he-pe \\
\hline
\end{tabular}

2012: 25-27). In comparison, Kișir-Nabû copied at least three such tablets with similar notes. These texts are presented in Table 14.

Considering all of Kișir-Aššur's and Kișir-Nabû's texts listed above, manuscripts with hepi-notes appear in the šamallû șehru- (BAM 129, N4 no. 237), mašmaššu șehru- (BAM 33), mašmaššu- (KAR 56), and mašmaš bit Aššur-phases (BAM 99). Furthermore, several of the texts from later phases include purpose statements (BAM 99, BAM 311, KAR 56). As shown in Section 3.3.1, the passage with these notes on breaks in Kișir-Aššur's N4 no. 237 duplicate the same passage in Kișir-Nabû's $K A R$ 56, and the notes on breaks are almost identical. Thus, the texts were likely copied from the same original, which may have been a damaged writing-board.

Clancier (2014: 53-55) considered the LB Uruk texts with hepi-notes as examples illustrating a student's ability to copy accurately, although such texts were essentially difficult to implement in practice. ${ }^{49}$ Worthington (2012: 26), on the other hand, has questioned the argument that hepi-statements represent careful transmission in order to avoid restoration, and he argued the existence of several examples of ancient careless restorations from especially the first millennium. Kișir-Aššur's šamallû șehru-phase tablet BAM 129 contains consecutive rows of entries that are also found on a tablet possibly related to the therapeutic Ugu series (Section 9.3.4). Perhaps one purpose of this tablet was to illustrate Kișir-Aššur's ability to copy precisely. However, Kișir-Aššur's

49 See also Gabbay and Jiménez 2019: 6o-61 and note 32, 63 note 43, 69 note 69; Monroe 2019: 131-132; Cancik-Kirschbaum and Kahl 2018: 19o; Gabbay 2016: 63-64. 
$B A M 99$ was copied by an assistant with a purpose statement (Maul 2010: 214 note 85 ). The assistant may therefore be responsible for the hepi-note, if we assume Kișir-Aššur would himself fill out the blanks when preparing the ritual. $B A M 99$ could have functioned as both an exercise for the student copying the manuscript, and a text for practical implementation by Kișir-Aššur. However, it is difficult to account for Kișir-Nabû's $K A R 56$, which was copied by himself with a purpose statement when he was mašmaššu. As a mašmaššs, Kișir-Nabû must have been able to fill out such breaks himself when copying the text.

While Kișir-Aššur's šamallû șehru-phase tablet BAM 129 could support Clancier's hypothesis described above, the use of purpose statements in some manuscripts argues against such a general interpretation. Therefore, the purpose(s) of all these notations cannot be properly evaluated presently. Regardless whether a copyist wrote from writing-boards or clay tablets, it is likely they would occasionally encounter a break in the original. Considering the few $\mathrm{N}_{4}$ tablets with hepi-notes, it is reasonable to assume that some copies contained unmarked restorations by the copyist.

\section{$7 \cdot 5$}

\section{A Discussion of the Dated Tablet KAR 267}

In August (9th of the month Ulülu) of 658 в E , Kișir-Aššur "quickly extracted" the single columned vertical tablet (țppu) KAR 267 that he "copied and checked according to its original".50 This text contains a ritual against a ghost and it is the only dated tablet by Kișir-Aššur (Maul 2010a: 205 and note 52 ). ${ }^{51}$ Unfortunately, the manuscript was not supplied with a title, and it therefore remains unclear during which part of his career Kișir-Aššur copied KAR 267. Unlike later NB and LB texts, the NA learned texts from especially $\mathrm{N}_{4}$ were rarely equipped with a date formula. ${ }^{52}$ Therefore, the addition of a date to KAR 267 is not only important to us, but may also have marked a special occasion for Kișir-Aššur.

In general, the ritual in $K A R 267$ intends to dispel a ghost or "confusional states" (ha $(y) y a t t u)$ from a man's body to the netherworld. ${ }^{53}$ Stol (1993: 42-44)

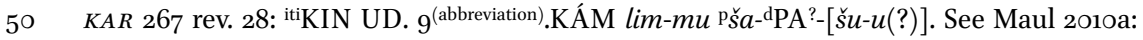
205 and note 52; Hunger 1968: 69, no. 199 ms B. The limmu can be found in Millard 1994: $53,120$.

51 Edited in Scurlock 2006 as no. 119-120 and Scurlock 1988b. See Ebeling 1931a: 138-42, no. 3oC; Farber 1987: 26o-61; Foster 1996: 554-55.

$5^{2}$ Gesche 2001: 50-51, 56; Pedersén 1986: 44; Hunger 1968: 16, 21.

53 Translation according to Scurlock 2006: 257; see KAR 267 obv. 2. The ritual may have been associated with the final prayer in bit rimki (Scurlock 1988b: 203; Læssøe 1955: 101), have 
translated the latter as a "fit" acting as a demon. Furthermore, a "fit" could produce symptoms such as flowing saliva, bending hands and feet, confused speech, fever and aching "strings", and it is connected to the expression for epilepsy, Antašubba (ibid.: 7-8, 44; see also Avalos 2007).

In accordance with the content, the month and date may relate to ghosts. However, a traditional ritual connected to ghosts occurring on the gth of Ulülu does not exist. Ап ов kispu ritual may have been performed on the gth of $A b u$ (Tsukimoto 1985: 48-49 with references), a MA ritual against a "fit" was performed on the 29th of the month $D u^{\prime} \bar{u} z u$ (Stol 1993: 43; Farber 1977: 141, 189; see Bottéro 1983: 193-96), another NA reference states that ghosts should be supplied with offerings on the 29th of $A b u$ (Tsukimoto 1985: 79; Farber 1977: 211-13, text III line 14), and in general a kispu ritual was performed in relation to the second New Year celebration in the month Tašrittu (Ambos 2013a: 45-46, 57-58; Tsukimoto 1985: 201-4). ${ }^{54}$

The month Ulülu was related to an aspect of Ištar and cleansing in Assyria, ${ }^{55}$ possibly through the word ullulu "to purify" (Cohen 1993: 322$) .56$ Various examples of intercalated second Ulülus are known from the 7 th century NA court, but not for the year 658 (Parpola 1983a: 45, 187, 381-82, 482). Noticeably, KișirNabû's commentary on "Marduk's Address to the Demons", N4 no. 163, states: "I am Asalluhi, who was created by his own decree, am I (to be interpreted) as follows: he is called Anšar (i.e., Aššur) on account of (the month) Ulülu". ${ }^{57}$

been performed in connection to the "Substitute King Ritual" (Parpola 1983a: XxVI), or have been related to the removal of a "curse" (Zilberg and Horowitz 2016: 182-83).

54 On the 1st-3rd of Tašrìtu, a ritual called šumma amēla ețemmu ișbassu was performed (Ambos 2013a: $57 \mathrm{ff.}$., 201ff.). KAR 267 actually opened with the (admittedly generic) line

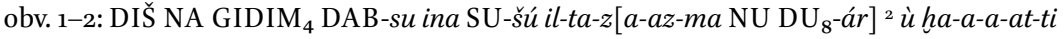
GIDIM $_{4}$ TUKU.MEŠ ${ }^{\top} \mathrm{x} \mathbf{x}^{\top}$ [(ca. 4 signs)], "If a ghost afflicts a person, stays continu[ously] in (his) body [and cannot be dispelled], and he continually has confusional states (caused by) a ghost [...]" (Scurlock 2006: 352, 357). Although these were not exactly the same rituals, they both included a prayer to Šamaš (Ambos 2013a: 204-6; Scurlock 2006: 358), and they concern some of the same problems. Although impossible to investigate completely here, KAR 267 may have been used similarly. For the New Year celebration(s) in Assyria, see Ambos 2013a: 181ff.; Siddall 2013: 20-21; Annus 2002: 90-94; Maul 200o; Parpola 1983a: 324; van Driel 1969: 162.

55 Also recorded in an inscription of Assurbanipal (Cohen 1993: 323; Borger 1996: 103, 225; cf. ibid.: 38, 226). The Assyrian Astrolabe B describes Elülu as "the work of the Elamite Ištar ..." (Wee 2016: 141 and note 82; Kolev 2013: 159; Cohen 1993: 322).

56 For Ulülu's possible relationship to Enlil or Ninurta, as well as the work song alālu or the word ulāla "the feeble", see Wee 2016: 127-28 note 4, 140-41, 143, 149.

57 Ass. 13955/gt; Frahm et al. 2016; Geller 2016: 393; Frahm 2011a: 124-25; Iraq 62 no. 35 obv. 1-2: ana-ku ${ }^{\mathrm{d}}$ asal-lú-hi šá ina ra-ma-ni-šú DÙ-u ${ }^{\top} a n a^{\top}-[k u]^{2}$ ma-a ina UGU ú-lu-lu AN.ŠÁR $q a^{\top} b i^{\top}$. 
The tablet does not contain a purpose statement, and was likely not aimed at a particular performance. Tanret (2011) argued in connection with the ов chief lamenter Ur-Utu that certain tablets were kept for the sake of remembrance and for creating a family identity, even though they had lost value and purpose. In line with the idea that tablets could hold commemorative purposes, I suggest the date attached to KAR 267 was (also) intended to commemorate a special day for Kișir-Aššur. The connection between Ulūlu and Aššur may supports this, although this remains conjecture. The present chapter argues that KiṣirAššrur's titles were important for his texts that are supplied with names until some time around the mašmaššu-phase. It is therefore plausible that KAR 267 was written during or after this phase. While it is unknown for what occasion the tablet was copied, we can entertain the idea that this text marked a special event for Kișir-Aššur in relation to copying a ritual suitable for a variety of private and official cultic duties. This situation may resemble the NB school texts dedicated under special circumstances to the Nabû-ša-harê temple in Babylon (Cavigneaux 1999a: 385-86, 388-91)

\subsection{Other Technical Literature: BAM $3{ }^{\circ} 7$ and ACh Supp. 224}

Perhaps following the instructions laid out in the EM, the lexical list $c T 37$ pl. 25 from Kișir-Aššur's mašmaššu-phase represents an aspect of his training towards becoming an "expert" (ummânu), as suggested in Section 9.4.1. It is therefore expected that he would also copy commentaries during this training phase. However, the only commentary certainly belonging to KișirAššur is $B A M 307$ without a title and possibly ACh Supp. 224 with a broken colophon. ${ }^{58}$ The latter text was excavated in Nineveh (K. 3145, see below).

The left side of $B A M 307$ is completely broken, but some lines provide alternative readings, suggesting that the composition had a commentary-like content. ${ }^{59}$ The focus was likely pharmacological, as the text lists plants and

$5^{8}$ Frahm (2011a: 144-45) suggests the text could have been written by Kișir-Nabû.

59 An example is rev. 25: [...] $]^{\top} \mathrm{x}^{\top}-\mathrm{u}: s \underline{u-p u r}$ an-zi-i : mur-din-nu, "[...] : the sheepfold of Anzû : amurdinnu-bramble" (see $C A D$ A/2: 90-91); rev. 19 refers to: [...] rit-ti an-zi-i na4[GÍR. TAB(?)], "the claw of Anzû (is) the [scorpion?]-stone" (see $C A D$ R: 386; CAD Z: 164); rev. 26 states: [...] $]^{\top} \mathrm{x}^{\top}:$ ga-bi-id UR.BAR.RA : gišbi-nu, "[...] : "wolf's liver"-plant : binu-tamarisk". The text may be a mythological commentary similar to Livingstone 1986: 176-79, which also mentions "cedar resin : the fat of Anzû", line 59: ÚŠ gišsEIN İ.GIŠ an-zi-i. For commentaries in the first millennium вCE, see Gabbay 2016; Frahm 2011a. 
stones. ${ }^{60}$ The relationship between pharmacopeia and commentaries are possibly echoed in a LB text from Borsippa, which states: "When you perform (a treatment of) plant, stone, and wood (for fumigation?), or the art of āšipūtu for the sick man - one does (it) in accord with its explanatory comment ${ }^{(?)}{ }^{\prime \prime}{ }^{61}$ However, unlike other $\mathrm{N}_{4}$ commentaries, $B A M 307$ does not use the $m \bar{a}$ particle to introduce explanations (Gabbay 2016: 31-34, 52-54; Frahm 2011a: 121-23, 269 and note 1278). Two aspects indicate that the tablet stems from at least KișirAššur's mašmaššu-phase, although the purpose of the text is uncertain. Firstly, as the only commentary-like text from Kiṣir-Aššur, the text fills the space occupied by commentaries foreshadowed to exist as part of the ummânu training via the EM (see Section 9.4). Secondly, the text was copied on behalf of KișirAššur whereupon he checked it ([ú-š $] a \check{s}$-țir-ma ib-ri). Although Kișir-Ǎšsur likely had a younger pupil copy an exercise as šamallû șehru (see Section 3.7.3), such uses of junior assistants have been suggested in this chapter as generally belonging to Kiṣir-Aššur's mašmaššu- and mašmaš büt Aššur-phases. An unresolved question is why Kișir-Aššur used someone to copy a tablet with esoteric content.

Additionally, Kiṣir-Aššur could have been the copyist of the commentary ACh Supp. 2 24. The colophon states: "for the 'reading' of Kiși $[\mathrm{r}-\ldots .$.$] ". { }^{62}$ Perhaps this Kișir-[...] was our Kișir-Aššur or Kișir-Nabû (Frahm 2011a: 144-45). KișirAššur has previously been suggested as a possible candidate, supplying manuscripts to the royal libraries (Maul 2010a: 205 and note 53; Villard 1998: 19). However, many NA individuals are attested with this name (cf. Baker 2000: 621ff.), and the content of the commentary concerns astrology, on which the $\mathrm{N}_{4}$ collection contains relatively few tablets (Pedersén 1986: 51; Frahm 2o11a: 270 and note 1279). It therefore remains uncertain if the tablet was copied by Kișir-Aššur and whether or not he studied astrology at all. ${ }^{63}$

6o Several lines refer to illness and cure, rev. 7: [...] KUR dUTU-ši ana IGIII.GIG.MEŠ SIG ${ }_{5}$, "[...] the rising of the sun is good for (damāqu) ill eyes" (see caD N/1: 267); rev. 11: [... ana

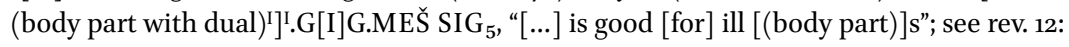
[...] NU TE, "[...] will not approach".

61 Rochberg 2015: 229 and note 88; Livingstone 1986: 73, cf. p. 7, 61-62, 96-97, 172-73, 163 255-56, 258. BM 34035 rev. 39-40 (on the copy by Epping and Strassmaier 1891: 243): ki-i Ú NA ${ }_{4} u$ GIŠ ̀̀ lúMAŠ.MAŠ-ú-tu a-na GIG te'-pu-šú ${ }^{40} i t-t i$ și-ti-šú e-pu-uš. As noted by Rochberg, Livingstone took șîtu as a singular of șâtu "explanatory word list(s)", which is always in plural. Rochberg (2015: 229 note 89) refers to a similar statement in another LB text. See also Heeßel 2008a: 9-12.

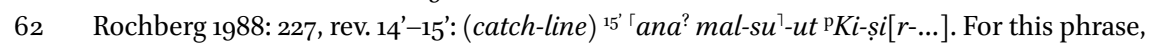
see Section 9.2.3. See also Frahm 2004: 47 note 18.

63 The text ends with two peculiar lines on the bottom of rev. 17'-18' stating: [... $]^{\top} \mathbf{x}^{\top}$ su-bar-tú ${ }^{18}$ [...] su-bar-tú ana ma-šu-šú-nu (Rochberg 1988: 227). 


\subsection{Summary}

This chapter has provided an overview of Kișir-Aššur's colophons without titles or possibly broken titles. Within these groups, internal features within the texts and colophons are useful for roughly allocating the tablets to various phases of Kișir-Aššur's career. Kișir-Aššur was probably more inclined towards writing comprehensive colophons earlier in his career, at which time he may have provided his title in a majority of colophons. Alternatively, as suggested in Section 5.4, the apprentice Kișir-Aššur would have provided the devout $\check{s} a$ Nabû tuklassu-phrase.

An important feature is Kișir-Aššur's use of the so-called "purpose statements", which were used to designate the texts as part of a specific ritual or healing ceremony. These statements do not occur in colophons with titles before Kișir-Aššur's mašmaššu-phase, and colophons with purpose statements, but without titles, must largely be assigned to Kișir-Aššur's mašmaššuand mašmaš bìt Aššur-phase. Kișir-Aššur was likely in a position to head rituals during these phases, and the possible accumulation of tablets with purpose statements during these phases would support this hypothesis. Kișir-Aššur's simultaneous use of assistants to copy tablets on his behalf for specific performances underlines this suggestion.

The present chapter also discussed Kișir-Aššur's sole dated tablet without a title, KAR 267 , and suggested it may have been copied in connection to an important event in Kișir-Aššur's career, possibly around his mašmaššu or mašmaš bit Aššur-phases. If KAR 267 truly belonged to either of these phases, it would imply that Kișir-Aššur functioned as mašmaššu or mašmaš bĭt Aššur in 658 в $\mathrm{B}$. However, this remains hypothetical. Finally, two examples of technical literature in the form of commentaries were discussed in relation to content. 